\title{
Pelargonium capitatum Oil
}

National Cancer Institute

\section{Source}

National Cancer Institute. Pelargonium capitatum Oil. NCI Thesaurus. Code C107343.

The essential oil of Pelargonium capitatum. Pelargonium capitatum oil is used for its aromatic properties and as an ing redient in skincare preparations. 